\title{
Esotericism Ancient and Modern
}

\section{Citation}

Frazer, Michael. 2006. Esotericism ancient and modern. Political Theory 34, no. 1: 33-61.

\section{Published Version}

http://dx.doi.org/10.1177/0090591705277770

\section{Permanent link}

http://nrs.harvard.edu/urn-3:HUL.InstRepos:3342973

\section{Terms of Use}

This article was downloaded from Harvard University's DASH repository, and is made available under the terms and conditions applicable to Other Posted Material, as set forth at http:// nrs.harvard.edu/urn-3:HUL.InstRepos:dash.current.terms-of-use\#LAA

\section{Share Your Story}

The Harvard community has made this article openly available.

Please share how this access benefits you. Submit a story.

\section{Accessibility}


The final, definitive version of this article was published in Political Theory 34:1, February 2006, pp. 33-61 by SAGE Publications, Inc. All rights reserved. (C) SAGE Publications, Inc. Available at http://online.sagepub.com.

\title{
Esotericism Ancient and Modern \\ Strauss Contra Straussianism on the Art of Political-Philosophical Writing \\ Michael L. Frazer
}

\begin{abstract}
Leo Strauss presents at least two distinct accounts of the idea that the authors in the political-philosophical canon have often masked their true teachings. A weaker account of esotericism, dependent on the contingent fact of persecution, is attributed to the moderns, while a stronger account, stemming from a necessary conflict between philosophy and society, is attributed to the ancients. Although most interpreters agree that Strauss here sides with the ancients, this view fails to consider the possibility that Strauss's writings on esotericism may themselves be composed esoterically. A reevaluation of Straussian hermeneutics in light of this possibility suggests that the elitism and secrecy often associated with "Straussianism" may stem, not from Strauss's true account of esotericism, but instead from an exoteric doctrine designed to seduce students into a life of philosophy.
\end{abstract}

Keywords: Leo Strauss; esoteric; persecution; writing; hermeneutics

Acknowledgements: This essay builds on work that I began under the supervision of Steven B. Smith as an undergraduate at Yale University; he has been my primary guide to the thought of Leo Strauss ever since. I would also like to thank Jonathan Allen, Leora Batnitzky, Coral Celeste, Patrick Deneen, George Kateb, Stephen Macedo, Wilson Carey McWilliams, Josiah Ober, Jeffrey Stout, Ian Ward, Micah Watson, Stephen White, Alex Zakaras and two anonymous reviewers for their valuable help. An earlier version of this essay was presented at the 2003 Annual Meeting of the APSA, and I would like to thank my fellow panelists—-Shadia Drury, Michael Kochin, Steven Lenzner, Arthur Melzer and Michael Moses-for their participation. 
"All I know is that I am not a Marxist." $-\operatorname{Karl} \operatorname{Marx}^{1}$

Perhaps the only indisputably true statement that one can make about the thought of Leo Strauss is that there is remarkably little agreement on what Leo Strauss truly thought; Strauss has been described as everything from an apolitical scholar of the classics to the secret mastermind behind a cabal of neoconservative neoimperialists, as everything from a liberal democrat (or at least a "friend" of liberal democracy) to a "Jewish Nazi." This disagreement is understandable, for there can be few interpretive tasks more challenging than that of uncovering Strauss's true teachings. Even if one is able to parse Strauss's dense and enigmatic prose, one is still plagued by the fact that Strauss, far more often than not, availed himself of what he called "the immunity of the commentator." It is thus difficult, if not impossible, to separate Strauss's doctrines from those he attributes to Plato and Xenophon, to Maimonides and Farabi, perhaps even to Machiavelli and Nietzsche. ${ }^{4}$

One of the few subjects which Strauss discusses in his own name, and not only as an interpreter of others, is the subject of interpretation itself. Central to Strauss's writings on the proper interpretation of canonical political-philosophical texts is the phenomenon of esotericism, the idea that the authors of these texts have often masked their true teachings. ${ }^{5}$ Strauss's writings on secret teachings, most famously the titular essay in Persecution and the Art of Writing, are thus commonly seen as possible keys to Strauss's own secrets. Those who seize on these writings, however, usually fail to consider the possibility that the Straussian doctrine of esotericism as it is most commonly understood - the ancient doctrine that esoteric writing is the 
only wise response to a necessary and eternal conflict between philosophy and society—may itself merely be exoteric.

A successful reevaluation of Strauss's writings on esotericism would thus prove invaluable to the evaluation both of Strauss's own work and of the phenomenon known as "Straussianism." My own attempt at such a re-evaluation will suggest that the ancient, inegalitarian account of esotericism most often associated with Straussianism may indeed not be Strauss's true account, but instead an exoteric doctrine designed to seduce students into a life of philosophy. ${ }^{6}$ Considering Strauss's esoteric writings on esotericism in terms of their pedagogical function will pave the way for a richer understanding — not only of the controversies surrounding Strauss, his students, and the alleged cult that they have formed within the academy_-but also of Strauss's understanding of what he called the "sociology of philosophy" $(P A W, \mathrm{p} .7)$, the nature of philosophy as a vocation and of its role in a polity, most pressingly in a liberal-democratic polity such as our own.

We need not go so far, however, as to consider the possibility that Strauss never actually believed any of the great thinkers of the Western tradition wrote esoterically, that the practice of esotericism is for him an entirely exoteric myth. Most classic philosophical works are obviously composed such that only a careful reader, a reader who thus might accurately be described as willing to read "between the lines" ( $P A W$, p. 24), will be able to grasp their full meaning. The only alternative is that these classics are simple books whose every nuance is accessible to all. In order to learn anything of significance from the trivial truth that philosophers often write esoterically, we must therefore provide a full account of this truth. As Stanley Rosen writes, 
"The serious question is not whether philosophers practiced esotericism—every thoughtful human being does so to one degree or another-but why."

This question is central to Strauss's hermeneutics; the reasons why philosophers write esoterically will shape how they write esoterically (to what degree they mask their true teachings, the stratagems they use to mask them, etc.), and thus in turn will shape how we can properly read their writings. The correct strategy for approaching esoteric texts, in other words, can only be determined through an account of the specific esoteric strategies used in their composition, which themselves can only be determined through an account of why these texts were written esoterically.

Unfortunately, rather than one clear answer to the question of why philosophers practice esotericism, Strauss provides at least two answers. The first of these answers, an account based on the straightforward fact that many regimes actively persecute those who openly express heterodox beliefs, dominates the essay "Persecution and the Art of Writing." In order to examine the "effect of that compulsion, or persecution, on thoughts as well as actions" (PAW, p. 22), Strauss here presents the "simple example" of a thinker (specifically, a "historian") who wishes to express some truth under a totalitarian regime that has made the expression of this truth punishable by death (p. 24). Such a thinker surely cannot express the truth openly and unambiguously except in private communications with his closest and most trusted friends. He can, however, express the truth secretly and ambiguously in his published works, so that an underpaid and overworked censor will miss the secret teaching, but a careful student will understand and appreciate it. That is, the philosopher under a totalitarian regime - or, for that matter, in any society that persecutes heterodox thought—can choose to write esoterically. Such a literary technique "has all the advantages of private communication without having its greatest 
disadvantage - that it reaches only the writer's acquaintances. It has all the advantages of public communication without having its greatest disadvantage - capital punishment for the author" (p. 25).

This account of the need for esoteric writing allows us to draw certain conclusions about the manner in which we may read philosophical works with an eye to the possibility that they may contain a secret teaching. For one thing, according to Strauss, it allows us to form a certain rule about when we may justifiably dismiss a work's obvious teaching as merely exoteric, and turn instead to finding an esoteric teaching written between the lines. "If it is true that there is a necessary correlation between persecution and writing between the lines," Strauss writes, "then there is a necessary negative criterion: that the book in question must have been composed in an era of persecution, that is, at a time when some political or other orthodoxy was enforced by law or custom" (p. 32).

Nowhere, however, has Strauss actually established a "necessary correlation between persecution and writing between the lines;" he has shown that persecution is a sufficient, but not a necessary, reason for the practice of esotericism, and there may still be other phenomena that also lead to this practice. Strauss himself presents such a possibility with a second account of the need for esotericism, an account which appears towards the end of the essay "Persecution and the Art of Writing," and which dominates Strauss's other writings on the subject. Rather than the contingent fact of persecution, this account relies on what is posited as an unchanging truth about the natures of political and philosophical life. As Strauss writes at the beginning of the essay "On a Forgotten Kind of Writing":

In studying certain earlier thinkers, I became aware of this way of conceiving the relation between the quest for truth (philosophy or science) and society: 
Philosophy or science, the highest activity of man, is the attempt to replace opinion about "all things" by knowledge of "all things"; but opinion is the element of society; philosophy or science is thus the attempt to dissolve the element in which society breathes, and thus it endangers society. ${ }^{8}$

There is a critical difference between an esotericism arising from a necessary gap between society and philosophy and an esotericism arising only from the contingent fact of persecution. While the conflict between the philosopher and society which leads to the need for esoteric writing is "accidental" under the latter account, it is a "necessary conflict... if the element of society is necessarily opinion" (WPP, p. 229). Paul J. Bagley thus calls the mode of writing engendered by Strauss's first account "conditional esotericism," while the second account leads to "unconditional esotericism." Not only will the "negative criterion" discussed earlier fail to hold under the latter of these accounts of esotericism, but, since it demands esoteric writing "unconditionally" - or, more properly, as a response to conditions which hold necessarily and at all times - no such negative criterion may be established under this account at all. ${ }^{10}$ The wise will always recognize the eternal conflict between political opinion and philosophical truth, and will thus choose to express difficult truths esoterically, "even if they... [have] nothing to fear from any political quarter" ( $P A W$, p. 34). The wise living in a "liberal" era will write esoterically, not out of fear, but out of respect for the need for political society and the opinions which are necessarily the "element" of such a society. Indeed, insofar as they understand the distinctive natures of philosophy and politics, the wise in a liberal society, who are absolutely free to refute society's opinions, will question "the wisdom of such extreme liberalism" (WPP, p. 224). They will thus write esoterically, not because of the wrongful and misguided actions of the regime under which they live, but despite them. 
Strauss presents the conflict between these two accounts of the need for, and hence character of, esotericism, like most other conflicts that he discusses, as a conflict between the ancients (a category which, for Strauss, includes all pre-Enlightenment thinkers, including medievals) and the moderns. The "unconditional" account of esotericism takes its inspiration from Plato's Seventh Letter, and finds its clearest expression among non-Christian Medievals such as Maimonides and Farabi, ${ }^{11}$ while the "conditional" account had a number of Enlightenment-era exponents, ${ }^{12}$ so Strauss's treatment of the debates over esotericism as yet another round in the great querelle des anciens et des modernes seems reasonable.

Such a presentation affords us greater insight into the two accounts, making it evident that they are indeed in conflict, that they cannot merely supplement each other as two separate but mutually compatible causes of the same phenomenon. The moderns hold to the persecution model because, according to the Enlightenment tradition, "suppression of free inquiry is accidental, an outcome of the faulty construction of the body politic" (PAW, p. 33). Philosophers who wish to practice their art freely should then make it their goal to "enlighten" their cities, to work to correct the flaws in regimes that have made cities hostile to the truth. This implies that society can indeed be built around the truth, a truth which the majority may not be able to embrace with the certain knowledge of philosophers, but which it can at least accept on their authority in the form of "true opinions." Esotericism can be a powerful tool for creating such a truth-based society, for it will undermine the false doctrines of the day, while nonetheless allowing the philosopher to live to see tomorrow. This will be an esotericism of a particular kind, however, a particularly weak esotericism. The moderns have almost invariably "concealed their views only far enough to protect themselves as well as possible from persecution; had they been 
more subtle than that, they would have defeated their purpose, which was to enlighten an everincreasing number of people who were not potential philosophers" (PAW, p. 34).

Strauss's ancients, on the other hand, understood the reasons for esotericism to be necessary and virtually eternal. The conflict between philosophy and politics is a result of an essential "gulf separating 'the wise' and 'the vulgar' ... a basic fact of human nature which could not be influenced by any progress of popular education" ( $P A W$, p. 34). A society for the mass of humanity cannot be built on the truth because the mass of humanity will reject the truth. Nor is their rejection unreasonable, for the truth will invariably be harmful except for a select few, the philosophers and the potential philosophers. Esotericism is thus the means for communicating truths dangerous to the multitude within the philosophical community, a community of unacquainted individuals living in different places and at different times but united through their secret communication. This stronger esotericism will produce texts far more inscrutable than esoteric texts in the modern mode. Rather than a tool for the enlightenment of all, esotericism here serves as a test, a test for admission into a secret (counter-)society.

A possible Straussian methodology for reading esoteric texts would seem to follow from this distinction. Ancient texts may be read as strongly esoteric works, while modern texts may be read as weakly esoteric works when written under a non-liberal regime, and must not be read between the lines at all when written under a liberal regime. The problem with such a methodology is that it assumes philosophers are captive to the ideas of their time and place, the very sort of historicist thinking which Strauss (at least exoterically) opposes so adamantly in so many of his writings. The truly wise will break free from the opinions of both the masses and of the intellectual elite of their day, and come to embrace the truth as it really is. Since a student of Strauss is interested in reading esoteric texts written by the truly wise, we cannot develop a 
Straussian hermeneutic for these works until we have established which of the two accounts is (according to Strauss) the true account.

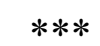

Some of Strauss's writings on the subject of esotericism, however, may tempt us to reject any real dichotomy between the ancient and modern accounts of esotericism, and to maintain that Strauss's true teaching must somehow be a synthesis or a reconciliation of these two views. Indeed, in one of Strauss's earliest discussions of the subject of esotericism, which comes at the end of a 1939 essay on Xenophon's Constitution of the Lacedemonians, there is as yet no distinction between ancient and modern accounts of esotericism. ${ }^{13}$ Having witnessed the execution of their friend Socrates, Xenophon and Plato were well aware (as were Herodotus and Thucydides before them) that philosophical impiety was at their time "subject to persecution;" esoteric writing allowed them to avoid Socrates' fate. Such writing's "disappearance was simultaneous with the disappearance of persecution, just as its reappearance is simultaneous with the reappearance of persecution."

Yet Strauss insists that it would "betray too low a view of the philosophic writers of the past if one assumed they concealed their thoughts merely for fear of persecution." Instead, they also kept their true teachings hidden out of the conviction that the truth is forever unsuited for the vulgar. Under this account, esoteric writing is a necessity recognized "in all epochs in which philosophy was understood in its full and challenging meaning, in all epochs, that is, in which wisdom was not separated from moderation.” The disappearance of esoteric writing is now observed to have occurred, not only with the disappearance of persecution, but also to have "almost" coincided "with the victory of higher criticism and of systems of philosophy which claimed to be sincere but which certainly lacked moderation." 
Rather than a harmonization of the ancient and modern accounts of esotericism, however, this early discussion of the subject by Strauss is rather clearly a presentation of the ancient account. There is nothing in the ancient account of the phenomenon which precludes the possibility of esotericism designed to avoid persecution; Strauss reports that Farabi—one of the great exponents of esotericism in the strong, ancient mode - acknowledges that persecution is indeed a sufficient reason for practicing esotericism, albeit "the most obvious and crudest reason" for doing so $(P A W, \mathrm{p} .17)$. As long as it is recognized that there are also reasons for practicing esotericism grounded in a permanent gap between philosophy and society, reasons which hold even when persecution ends, an account of esotericism qualifies as unconditional. It is thus clear that the two accounts of esotericism can never really be reconciled; either there are necessary sufficient for this practice grounded in the unchanging natures of society and philosophy or there are not, and the mere mention of persecution does not render an account of esotericism conditional or "modern" if these eternal reasons are acknowledged as binding. The fact that the disappearance of persecution "almost" coincided with the disappearance of philosophical moderation - that is, with the loss of the knowledge of the "unconditional" reasons for practicing esotericism—admittedly allows for the appearance of ambiguity in Strauss's 1939 discussion of this subject. Nonetheless, there is no doubt that Xenophon's esotericism was primarily motivated by consideration of the natures of society and philosophy; the contingent fact of persecution can be said to have left his choice over-determined, but its absence would not have altered his esotericism.

This should come as no surprise from an ancient author, but what is striking here is that Strauss is not merely providing the ancient account of esotericism in his role as an interpreter of Xenophon, but also appears to be endorsing this ancient doctrine in his own name, holding it to 
follow necessarily from a "full" understanding of philosophy and the practice of the virtue of "moderation." Those, such as Shadia Drury, who wish to attribute the ancient account of esotericism to Strauss have seized on Strauss's 1939 essay as the text in which he most "clearly" states the doctrine "that esotericism is not just an attempt to escape persecution, but a duty, because the vulgar are unfit for the truth. ${ }^{, 14}$ Similar, if somewhat more ambiguous, statements which appear to endorse the ancient account of esotericism are to be found scattered throughout Strauss's writings on the subject. ${ }^{15}$ Indeed, if "Straussianism" is understood as a largely uncritical return to ancient political philosophy, it would follow that Strauss would side with the ancients on the subject of esotericism, as he would on all other such matters. ${ }^{16}$ The view of Strauss as advocating the ancient account of esotericism over the modern may thus be accurately described as the conventional interpretation of his doctrine on esotericism. Indeed, both the exponents and the opponents of "Straussian" esotericism have tended to identify this practice with ancient, unconditional esotericism, rather than with the modern, conditional esotericism which Strauss also describes. ${ }^{17}$

It is critical to note, however, that under both the ancient and the modern account of esotericism, Strauss himself ought to be writing esoterically. The ancient account, of course, would make esotericism as much an intelligible necessity for Strauss in his day as it was for Plato or Maimonides in theirs. Even under the modern model, however, the political conditions of the United States in the mid-twentieth century were not so free as to allow for a complete abandonment of esoteric modes of expression. The persecution that is the precondition for esoteric writing under this account "covers a wide variety of phenomena, ranging from the most cruel type, as exemplified by the Spanish Inquisition, to the mildest, which is social ostracism" 
( $P A W$, p. 32). It is for this reason that, under the modern model, esoteric writing may be needed even in "comparatively liberal periods," even in times and places with such hallmarks of liberalism as complete religious freedom, for "religious persecution and persecution of free inquiry are not identical" ( $P A W$, p. 33). Recall also that this persecution may be the result of either law or custom. "Social ostracism" may thus be the fate of those who openly and publicly express heterodox views even in nations where an absolute right to freedom of speech is guaranteed by law. This is not to say that there are not eras of "extreme liberalism" in certain countries when esotericism becomes entirely unnecessary. When pressed for examples of such societies "in which men can attack in writings accessible to all both the established social or political order and the beliefs on which it is based," however, Strauss offers "the third Republic in France and post-Bismarckian Wilhelmian Germany" (WPP, p. 224). He notably excludes the United States of the twentieth-century.

This exclusion is eminently sensible in light of the historical circumstances. The essay "Persecution and the Art of Writing" was, after all, the work of a German-Jewish refugee first published less than a month before the United States entered World War II. Even the most just war is a time of censorship and the devaluation of free expression, albeit as a necessary sacrifice to protect freedom itself from grave dangers, dangers that Strauss himself alludes to in the opening lines of his essay. Even after the war, however, freedom of expression was far from fully actualized in the American republic. In "On a Forgotten Kind of Writing," first published in 1954, Strauss praises a man who understands that there are "contemporary dangers to intellectual freedom... caused, not only by men like Senator McCarthy, but by the absurd dogmatism of certain academic 'liberals' or 'scientific' social scientists as well” (WPP, p. 223). While the 
esotericism required under the modern model by such "mild" persecution might not be especially strong, it is esotericism nonetheless.

Though we are as yet unsure whether to apply the modern or the ancient model to Strauss's own use of esotericism, we can thus be certain that, to one degree or another, his works are indeed esoterically written. This is far from an original discovery; many of the most insightful commentators on Strauss in recent years, among both Strauss's admirers and his critics, have begun from the premise that Strauss's works mask a hidden teaching. Indeed, Strauss is today often remembered not merely as a political philosopher in the sense of a theorist of political things, but also as a politic philosopher, a philosopher who was a master of the art of esoteric speech and writing. ${ }^{18}$ It is thus no surprise that a careful commentator would begin by observing that for Strauss the philosophical practice of esotericism is the essence of "political" philosophy, as Strauss observed it was for Farabi (PAW, p. 18).

Most such commentators adhere to the conventional view that Strauss is an adherent to the ancient account of esotericism, and thus that he must be writing in a strongly esoteric manner. ${ }^{19}$ The Strauss that emerges from such an analysis is often a sort of secret Nietzsche, an immoralist and inegalitarian for whom the Platonic philosopher-king is an exoteric stand-in for the Overman, and the return to ancient natural right a stand-in for the will to power. The one critical difference between Strauss and Nietzsche, however, is that while Nietzsche screamed out his terrible truths in bold German prose, Strauss hid his away amid drawn-out scholarly exegeses on the traditional canon. In other words, Strauss is held to be esotericist in the ancient mold, while Nietzsche holds the modern view; living in Wilhelmian Germany, and under no great threat of persecution, Nietzsche saw no need to practice esotericism. ${ }^{20}$ Laurence Lampert thus 
attacks Strauss in Nietzsche's name, insisting that Strauss shows an insufferable "lack of boldness on behalf of philosophy at a decisive moment in its history."21

The more liberal Shadia Drury also criticizes Strauss for adhering to the ancient mode of esotericism, not for the lack of boldness it shows, but for the extreme inegalitarianism it presupposes, inegalitarianism in some ways more profound than even Nietzsche's. Drury sees this account of esotericism to imply that "the gap between the vulgar and the wise is so great" that "there is one rule for citizens and another rule for the wise and powerful." ${ }^{, 2}$ We must reject Strauss, because in embracing the ancient account of esotericism, he rejects the validity of a single morality for all of humanity. Of course, Strauss foresaw that most of his modern readers would be morally outraged by his teachings on esotericism, especially if these teachings are understood as advocating the ancient, stronger version of esotericism. "Every decent modern reader," he wrote, "is bound to be shocked by the mere suggestion that a great man may have deliberately deceived the large majority of his readers" ( $P A W$, p. 35). Such is Drury's shock, and while Nietzscheans such as Lampert may be less "decent" than Drury, they still can find sufficient cause to object to Strauss's supposed ancient esotericism.

The majority of Strauss's commentators, however, regardless of whether they are admirers or critics, fail to follow their line of argument to its logical conclusion. If Strauss's teaching on all other matters is merely exoterically Platonic or ancient while esoterically Nietzschean or modern, we must also consider the possibility that his teaching on esotericism itself is merely exoterically ancient while esoterically modern. No teaching of Strauss's deserves to be exempted from critical scrutiny; upon such scrutiny, any one of these teachings, even Strauss's teaching on esotericism itself, may reveal itself to be an exoteric mask hiding a deeper, esoteric truth. ${ }^{23}$ We must thus consider the possibility that Bagley is correct when he writes, in a 
footnote to his 1992 essay, "If Strauss is guilty of anything, it is that he wrote esoterically about esotericism.' ${ }^{24}$ Unfortunately, Bagley, who is more concerned with making skeptical antiStraussians take esotericism seriously than with interpreting Strauss's position on the subject, fails to develop this observation any further.

Of all of the commentators on Strauss of whom I am aware, Stanley Rosen comes closest to Bagley's position. "Strauss's revelation of esoteric teachings, with respect to the 'early' or pre-Enlightenment philosophers," he writes, "was itself exoteric." By this, however, Rosen does not mean that Strauss's teaching on esotericism might be merely exoteric. Rather, Rosen implies that in his commentaries on the ancient authors Strauss's implication that he understands these author's secret teachings might be an exoteric falsehood, because Strauss very possibly "did not know the original teaching." Rosen concludes that this possibility "makes no difference" because "in order to understand Strauss himself, we need to start from his own practice of esotericism," that is, his practice of esotericism in the strong, ancient mode. ${ }^{25}$ Though he is willing to undermine the conventional understanding of nearly all that Strauss wrote, Rosen is thus unwilling to undermine the conventional understanding of Strauss's writings on esotericism.

It is thus necessary to make one's own attempt to read between the lines of Strauss's doctrine of reading between the lines. A good way to start might be by applying Strauss's methodology for reading esoteric texts to Strauss's own writings on esotericism. Yet practicing Straussian hermeneutics is always fraught with difficulties. For Strauss, as Paul Cantor has noted, "interpretation cannot hope to proceed according to universal and unequivocal rules, which will always yield unambiguous and unassailable results... One can offer principles of interpretation, but not rules, unless one means rules in the sense of rules of thumb." ${ }^{26}$ It is for 
this reason that Strauss granted his detractors their argument that "the method of reading which I suggest can never lead to absolute certainty." Strauss, however, then asks rhetorically, "Do the alternative methods of reading lead to absolute certainty?" (WPP, p. 231). ${ }^{27}$ Yet if applying this method to any esoteric text is a difficult task with uncertain results, then applying them to Strauss's own esoteric texts on esotericism will be doubly difficult, and yield results twice as uncertain.

"One of Strauss's rules of thumb for interpreting esoteric texts," Cantor writes, "is to pay close attention to what goes on at or near the middle of a work, and to discount what is said at the beginning or the end."28 This rule of thumb is little help to us here, however. "Persecution and the Art of Writing" may begin with the modern model, but it introduces the ancient model not in the middle section of the essay (which is devoted to the nature of reading between the lines, a discussion presumably valid under both models) but in the final section. Other essays, such as "On a Forgotten Kind of Writing," are devoted entirely to the ancient model, beginning, middle and end.

Strauss also insists that, in reading an esoteric text, one pay special attention to conditional and qualified language. "Cannot miracles be wrought by such little words as 'almost,' 'perhaps,' and 'seemingly'?" he asks. "May not a statement assume a different shade of meaning by being cast in the form of a conditional sentence? And is it not possible to hide the conditional nature of such a sentence by turning it into a very long sentence...?" ( $P A W$, p. 78$)$. Sure enough, conditionals are to be found throughout Strauss's discussions of ancient, unconditional esotericism, especially when Strauss presents the eternal conflict between the philosopher and the city. "There is a necessary conflict between philosophy and politics if the element of society necessarily is opinion," Strauss writes on one occasion (WPP, p. 229, italics 
added). Might this suggest that, despite the conventional view to the contrary, Strauss may indeed be an advocate of the modern view of esotericism? Perhaps, but his discussion of the modern view in "Persecution and the Art of Writing" is also filled with conditional and qualified sentences. When introducing the "negative criterion" discussed earlier, recall that Strauss said such a criterion holds only "if it is true that there is a necessary correlation between persecution and writing between the lines" ( $P A W$, p. 32, italics added).

We surely cannot exclude from our analysis the most (in)famous of Strauss's rules of thumb for reading between the lines. "Secrecy is to a certain extent identical with rarity," Strauss reasons in his essay on Maimonides's esoteric techniques. "What all people say all the time is the opposite of a secret. We may therefore establish the rule that of two contradictory statements in the Guide or in any other work of Maimonides that statement which occurs least frequently, or even which occurs only once, was considered by him to be true" (PAW, p. 73). Again, this principle of interpretation is of little use in our situation, for while the modern model is discussed with great frequency in "Persecution and the Art of Writing," the ancient model is discussed more frequently in Strauss's other writings on esotericism. One should also note that it is the ancient model that is presented most frequently in Strauss's commentaries, ${ }^{29}$ but this can be explained as a result of the fact that Strauss's commentaries are most often on pre-modern thinkers who advocated the unconditional model of esotericism. Discussions of their ancient views might then be understood as merely reflecting these views, and thus would not enter into an investigation of Strauss's own position.

On the other hand, this conclusion may be inappropriate when considering an esoterically written commentary. Farabi, after all, "avails himself... of the specific immunity of the commentator or of the historian in order to speak his mind concerning grave matters in his 
'historical' works rather than in the works in which he speaks in his own name" $(P A W, \mathrm{p} .14) .{ }^{30}$ So are we then to conclude that, since Strauss most often defends the ancient account of esotericism in his commentaries, while defending the modern account in his own name, the ancient account is his true account? Or are we to conclude that, since both his commentaries and the works in his own name are to be treated as containing Strauss's true teachings, the ancient account is the more frequently defended account while the modern account is less frequently defended, and thus that the modern account is Strauss's true account? There is, quite simply, no way to tell.

Even more troublingly, it may have been a mistake to turn to Strauss's interpretive methodology in the first place, for we must be open to the possibility that this methodology is itself exoteric, or at least an inappropriate tool for uncovering Strauss's true teaching on esotericism. Indeed, it seems that most of these rules of thumb for reading between the lines were developed by Strauss for reading pre-Enlightenment works written in the strong, ancient esoteric manner. While these techniques may perhaps be valid for the reading of such works, to apply them to Strauss means to assume that he too wrote in the ancient esoteric manner, and thus that he was a believer in the unconditional account of esotericism. That is, in our attempt to call the conventional understanding of Strauss's teaching on esotericism into question, we have been perversely assuming the validity of that very interpretation.

We are caught in a double bind, for any possibly valid reading of a text by Strauss must legitimate its interpretive principles in the thought of Strauss himself; to do otherwise is to assume that the interpreter can understand Strauss better than he understood himself, the tell-tale hubris of a historicist. As soon as one attempts to ground one's interpretive principles in some particular statement by Strauss, however, one is groundlessly assuming that this statement 
reflects Strauss's true beliefs, that it is not just another noble lie. This problem becomes all the more acute when the Straussian texts one is attempting to interpret are the very same texts in which one is attempting to ground one's allegedly Straussian interpretive principles, that is, those texts on the reading of esoterically written texts.

Yet if any text of Strauss's is an unreliable hermeneutic guide because its teachings might be merely exoteric, perhaps we can turn, not to Strauss's words, but to his deeds. ${ }^{31}$ Presenting exoteric falsehoods in their speeches and writings in order to hide dangerous truths can only be of benefit to philosophers. Living according to those falsehoods, however, can only serve to harm them, depriving them of the excellence attainable only through a life in accordance with a true understanding of the world and our place within it. Strauss's relevant actions here are twofold: First, Strauss chose the life of a teacher and a scholar. Second, as a scholar, Strauss built his reputation, not only through the insight of his commentaries and the loyalty of his students, but as the re-discoverer of "a forgotten kind of writing."

By writing on the subject of esotericism, a subject that had been neglected for centuries, as well as by interpreting the classics of political philosophy in light of their esoteric nature, Strauss made at least some of the secrets of the philosophers available to all. Though his writings are never easy or clear, they surely unmask the secrets of the classics to some degree. Yet there is only one passage in his published works in which Strauss directly attempts to justify his disregard for the esotericist intentions of the authors he is interpreting. Like many of Strauss's most important passages dealing with the issue of esotericism, it is a passage on Maimonidesthe fourth of six sections of the essay on "The Literary Character of the Guide for the Perplexed," a section entitled "A Moral Dilemma." Strauss here writes that "no historian who 
has a sense of decency and therefore a sense of respect for a superior man such as Maimonides will disregard light-heartedly the latter's entreaty not to explain the secret teaching of the Guide" (PAW, p. 55). How, then, does Strauss justify his revelation of these secrets?

Strauss's justification is twofold. First, Strauss writes that "the historical situation in which we find ourselves is fundamentally different from that of the twelfth century." In a passage quoted at length by Rosen, and well worth quoting at length yet again, Strauss goes on to explain:

Public opinion was then ruled by the belief in... the existence of an eternal and unchangeable law, whereas public opinion today is ruled by historic consciousness. Maimonides himself justified his transgression of the Talmudic injunction against writing on the esoteric teaching of the Bible by the necessity of saving the law. In the same way, we may justify our disregard of Maimonides' entreaty not to explain the Guide by appealing to the requirements of historic research... The force of this argument will become even stronger if we take into consideration the basic condition of historic research, namely, freedom of thought. Freedom of thought... seems to be incomplete as long as we recognize the validity of any prohibition to explain any teaching whatsoever. Freedom of thought being menaced in our time more than for several centuries, we have not only the right but even the duty to explain the teaching of Maimonides, in order to contribute to a better understanding of what freedom of thought means, i.e., what attitude it presupposes and what sacrifices it requires ( $P A W$, pp. 55-56).

This passage does not merely present a change in historical situation; it presents a change in fundamental values, with Strauss defending his revelation of Maimonides' secret teachings in 
terms of the values of his day as Maimonides defended his revelation of the Bible's secret teachings in terms of the values of his. Such a justification implies that Strauss has himself embraced the modern values of historic consciousness and freedom of thought; unless one is to embrace historicism, one must acknowledge the freedom of authors to accept or reject the values that dominate their eras. In other words, as Rosen writes, "If this statement were taken as a frank assertion of Strauss's own views, we would have to conclude that he accepted the contemporary liberal principle of unreserved freedom of speech and hence that he was, as it were, an Enlightenment philosopher. ${ }^{, 32}$ For our purposes, this means that if the passage in question were not merely exoteric, it would imply Strauss is an advocate of the modern account of esotericism. In typical Straussian fashion, however, this passage is immediately followed by a contradictory argument justifying Strauss's actions, an argument compatible only with the ancient view of esotericism.

Maimonides, himself an advocate of the ancient view of esotericism, felt that he could save the Bible and its law by communicating its secret teaching, not to all, but to the few philosophically-minded souls capable of understanding and appreciating this secret teaching. To do so, he wrote an esoteric commentary on the teachings of the Bible, itself an esoteric work. If he were to follow Maimonides' model, Strauss reasons, the interpreter of the Guide would thus write his commentary in "the form of an esoteric interpretation of an esoteric interpretation of an esoteric teaching." While Strauss admits, "this suggestion sounds paradoxical or even ridiculous," he concludes, "an esoteric interpretation of the Guide seems to be not only advisable, but even necessary" ( $P A W$, p. 56). Clearly, this contradicts the earlier claim that "we have not only the right but even the duty to explain the teaching of Maimonides" in a manner that advances the cause of freedom of thought. So which is the true teaching and which the 
merely exoteric? We could conceivably attempt to re-apply the Straussian methodology for reading esoterically written texts to this apparently contradictory passage, but such a procedure has been demonstrated to be both practically useless and theoretically unsound. Instead, we must turn to the evidence provided by Strauss's deeds. Did Strauss reveal the secret teaching of the Guide in a manner so as to advance the cause of freedom of thought for all, or did he only esoterically hint at this teaching in a manner of benefit only to the philosophical few?

In fact, Strauss did neither of these things. As Rosen correctly points out, "Despite Strauss's extensive discussions in various places of Maimonides' intentions and methods, he never did reveal 'the secret par excellence of the Guide." ${ }^{, 33}$ Rosen would like to attribute this either to the fact that Strauss's claim to know Maimonides' secret teaching was a merely exoteric claim, or that Maimonides himself falsely claimed to be masking a secret teaching within the Guide. Nonetheless, Rosen acknowledges the possibility that he has simply been unable to find the secret because Strauss has hidden it so well. In this case, "Strauss could hardly be practicing either the concealment or the revelation characteristic of the Enlightenment," with it understood by Rosen that Strauss would then be practicing the ancient form of esotericism. ${ }^{34}$ What Rosen fails to consider, however, is that Strauss's treatment of Maimonides' secrets may represent a break from both the ancient and Enlightenment modes of esotericism.

Indeed, rather than revealing Maimonides' secrets to all or hiding them away from all but a very few, Strauss provides his readers with a method for reading Maimonides which, with the proper effort, should yield up any secrets that the rabbi might be hiding. The methodological nature of most of Strauss's work on Maimonides is evident from the very titles of all but his earliest writings on the sage—-titles such as "The Literary Character of the Guide..." "How to Begin to Study the Guide..." "How to Begin to Study Medieval Philosophy," and so on. The 
methodology that these essays describe is neither hidden nor obscure, but available to any beginner with sufficient interest and patience to put difficult and demanding techniques of interpretation to work on a classic text. Insofar as its presentation is such that Strauss's methodological teaching is accessible to all, it is entirely incompatible with the ancient view of esotericism. Yet insofar as Strauss presents methods which few will be willing to go through the effort of carrying out rather than doctrines which will enlighten all, he is also not acting in a manner consistent with the modern account of the matter.

As for Strauss's commentaries on other esoteric writers, while they might not be as uniformly methodological as his commentaries on Maimonides, they all have a similar effect of forcing Strauss's readers to return to the classic texts themselves. Nowhere are secrets presented in a manner suitable for acceptance by the masses, for serving as "true opinions" from which an enlightened society can be built. Instead, the student of Strauss, whoever he or she may be, is compelled to become a student of the philosophical masters that Strauss analyzes. ${ }^{35}$ Upon returning to the masters after reading Strauss, however, Strauss's students are equipped with a host of new insights and new hermeneutic techniques. Strauss's goal thus seems neither to be for the philosophers to enlighten all of humanity by reshaping society, nor for the philosophers to forever hide their secret teachings from all but a chosen few. Instead, he seems to be inviting anyone who is willing to make the effort to become one of the philosophers.

That Strauss's true view on esotericism would not fit neatly into either the ancient or the modern models of the phenomenon was to be expected. While we had good reason to be dubious of the conventional interpretation of Strauss's teaching as identical with the ancient account of esotericism, there are also insurmountable problems with positing Strauss's teaching as identical with the modern, Enlightenment account of esotericism. Such a correspondence between 
Strauss's true account of esotericism and the modern account would mean that all those passages that have convinced most interpreters that Strauss is in fact an advocate of the ancient account would be merely exoteric. Furthermore, this exoteric advocacy of the ancient account of esotericism must be meant in some way to protect Strauss from some form of persecution, for (provided again that the modern, conditional account of esotericism is the true account) there can be no reason to write esoterically except to avoid such persecution. Admittedly, if Strauss were indeed the secret Nietzsche many of his interpreters have claimed him to be, it would still follow from this modern esoteric model that he should discuss many of his true philosophical and political beliefs esoterically. After all, as is well known, anything but whole-hearted commitment to liberal democracy in its battles with fascism and communism could have disastrous results for a public figure in mid-twentieth century America.

Yet while this may explain Strauss's use of esoteric techniques in his discussions of, for example, ancient natural right, it cannot explain his use of esoteric techniques in his discussions of esotericism. More specifically, it cannot explain why he would want the vulgar reader to believe he was advocating the ancient, stronger account of esotericism rather than the modern, weaker account. It would seem that the modern account of esotericism would be more amenable to most mid-twentieth century Americans than the ancient account, especially to the coterie of "academic 'liberals' or 'scientific' social scientists" who had the power to practice "social ostracism" within the American academic community. ${ }^{36}$ Indeed, it would seem that an exoteric appearance of support for the ancient model of esotericism could lead, as Rosen notes, only to "almost unmitigated ridicule, not to say persecution, at least in the English-speaking academy."37 
We must thus introduce a new account of esotericism that is compatible with Strauss's deeds, if not always his words. To do so, let us turn to Strauss's most fundamental of real-life decisions, his choice to lead the life of a scholar, teacher and (despite his repeated assertions that he is unworthy of the designation) philosopher. This choice of life must mean that, at least for those who are capable of it, the philosophical life is indeed a good life, perhaps even the good life. The second best life may then be one devoted to the study of the work left by these true philosophers, scholarship undertaken in the hope that, with sufficient intellectual struggle, one may someday prove worthy of joining their ranks. Strauss's writings defending this positionhis often hyperbolic odes to the philosophical vocation - cannot be entirely exoteric. Since such sentiments are reflected in Strauss's deeds as well as his words, we are safe in assuming they reflect at most an exaggeration of his true position on the subject. Strauss writes that, in a world of suffering:

We have no comfort other than that inherent in this activity [of philosophy]... It leads us to realize that all evils are in a sense necessary if there is to be understanding. It enables us to accept all evils which befall us and which may well break our hearts in the spirit of good citizens of the city of God. By becoming aware of the dignity of the mind, we realize the true ground of the dignity of man and therewith the goodness of the world... which is the home of man because it is the home of the human mind (LAM, p. 8).

Even if Strauss truly believes that the philosophical way of life is the best way of life, he also insists that philosophers are still always "in grave danger," albeit not necessarily from persecution. Instead, each is in danger of being the last of their kind, of witnessing the extinction of philosophers as such. This is because, while the philosophical life once actualized is one of 
great joy, the years of effort necessary to attain this sort of life are invariably difficult and unpleasant. "The movement from the untruth to the truth is not simply a movement from unrelieved darkness and terror to pure light and joys," Strauss writes. "On the contrary, the truth appears at first to be repulsive and depressing" (LAM, p. 83). Most potential philosophers (a group which could conceivably include anything from a very small elite or the whole of humanity) will thus be driven away from the philosophical life before they can experience its joys. The danger that none will chose even to begin such a difficult journey is especially acute in today's society, a society in which "mass culture" distracts us from our quotidian miseries "without any intellectual and moral effort whatsoever and at a very low monetary price" (LAM, p. 5). Under Strauss's account, those who are distracted by mass culture are neither hostile to nor in favor of the philosophical life, but view it with a sort of indifference. They cannot understand why potential philosophers would deprive themselves of readily available pleasures on a quixotic quest for truth, and they are merely repulsed by their fleeting encounters with philosophy. Thus, in order to insure that the tradition of philosophical living can be preserved for future generations, Strauss concludes that "a special effort is needed to counteract the first appearance of the truth" (LAM, p. 83).

In his "Notes on Lucretius," Strauss suggests that this "special effort" ought to be in the form of poetry ( $L A M$ p. 83). Although Lucretius used actual verse, esoteric prose seems an even better "poetic" form for gradually acclimating potential philosophers to the truth. Rather than bombard initiates with teachings that they will only find "repulsive and depressing," esotericism provides a method for slowly luring them to search for "those hidden treasures which disclose themselves only after very long, never easy, but always pleasant work" (PAW, p. 37). Esoteric communication, moreover, has the pedagogic advantage of forcing students to think for 
themselves, to consider whether a philosopher's reasoning at any given time is sound and reveals his true teaching or is merely exoteric. In this way, students may almost be said to discover the truth through their own reasoning — that is, almost to be practicing genuine philosophy. ${ }^{38}$ We can call this new account of esotericism the "educational" or "pedagogical" account, and it seems to be the best candidate for Strauss's true teaching on the subject.

Is the educational account of esotericism, however, truly distinct from the ancient and modern accounts of the phenomenon? After all, any communication of truths is ipso facto educational; a concern for the education of others by the writer must be presupposed in both the ancient and modern accounts of esotericism. Fearing persecution, or believing that the dissemination of certain teachings is inherently harmful to society, the philosopher could easily remain silent. A decision to communicate, to write esoterically in either the ancient or the modern mode, can only be attributed to a desire to educate "the puppies of his race" ( $P A W, \mathrm{p}$. 36), that is, potential philosophers. Indeed, Strauss presents the educational purpose of esotericism at the end of "Persecution and the Art of Writing," not as a new and different account of the phenomenon, but as an essential element of both of the two accounts he has already presented; ${ }^{39}$ this is also how the educational purpose of esotericism has been described by most of Strauss's interpreters. $^{40}$

Strauss even characterizes the difference between the ancient and modern forms of esotericism as a difference in the belief as to whom this education ought to be directed, a difference in what is believed "about popular education and its limits" ( $P A W$, p. 33). According to the ancients, only a very small minority, a tiny elite of potential philosophers, can benefit from an education through esoteric writing. According to the moderns, however, even if not all can become philosophers, all can benefit from a philosophical education. Strauss might plausibly be 
said to take a middle position between the ancients and the moderns on this question. To be sure, we will never have the resources to offer a full liberal education to all; Strauss insists that "we must not expect liberal education can ever become universal education. It will always remain the obligation and the privilege of a minority" ( $L A M$, p. 24$)$. Yet Strauss clearly imagines that this minority will extend beyond the even smaller elite of potential philosophers; it also includes a considerable number of non-philosophical "gentlemen." And while Strauss would admit that once philosophical education is made available to more than a very tiny few, most of those who receive this education will never move beyond philosophical scholarship to genuine philosophy — most will never graduate from studying the thought of others to producing original thought of their own — he would still insist that the life of students and scholars who do not themselves qualify as philosophers is both inherently valuable and a necessary to maintain the philosophical way of life as a possibility for others. A broad community of philosophicallyliterate non-philosophers, Strauss would argue, is needed both to preserve the insights of past philosophers and to establish an atmosphere of free enquiry so that new philosophers can be expected to emerge in the future. ${ }^{41}$

Yet while a concern for education may be essential for esoteric writers both ancient and modern, one would be consistent in rejecting both the ancient and modern models of esotericism and still writing esoterically out of a concern for education. Those concerned exclusively with the educational uses of esotericism might be willing to adopt exoteric masks which actually lead to greater persecution (thus violating the modern model) and greater harm to society and its opinions (thus violating the ancient model) than would result if they openly taught the secrets that they have hidden for purely pedagogical purposes. Indeed, the exoteric masks that educators adopt might actually be less orthodox than the rather commonplace truths that they are masking, 
secrets that don't really qualify as secret. It would seem that Strauss's exoteric advocacy of the ancient model of esotericism is exactly such an educational use of the art of esotericism, one which is incompatible with both the modern and the ancient accounts of the phenomenon. Appearing to adhere to the ancient, inegalitarian account of esotericism can only serve to draw the wrath of decent liberals, and may even do real harm to our liberal democratic society, but it might be an effective solution to a central problem in philosophical pedagogy.

Strauss's problem is straightforward but immensely difficult: he must lure students away from mass culture and lead them down the long road to the philosophical way of life. He must do so, not only out of love for his students, but to insure that the possibility of a philosophical way of life is available to future generations. Most problematically, he must lure young men and women, not only from mass culture as instantiated in popular entertainment, but also from mass culture as instantiated in the fashionable non-philosophy of "certain academic 'liberals' or 'scientific' social scientists.” As David Lewis Schaefer has observed, Strauss’s academic competitors could easily "recruit followers by espousing partisan political causes in their classes or by flattering students' prejudices in favor of 'idealism' or 'compassion." In this way, "the academy becomes the servant rather than the critic of unreflective passions." ${ }^{42}$ Strauss, too, must appeal to his student's passions in order to recruit them as philosophers, but he must so shape these passions that they will compel the students to do what the passions would otherwise oppose, to begin the long and difficult journey to wisdom. Strauss must thus play the part of the seducer, and exoteric allegiance to the ancient model of esotericism may play a critical role in this process of seduction.

First, the possibility of a treasure-hunt through the classics of the philosophical canon, the chance to search for secrets where once there were only dry doctrines, is, as Lampert says, "so 
entertaining in its intricacies, so intoxicating in its audacity"43 that it can make difficult study of philosophical texts feel like a grand game. Only after the game is over, only after the puppies grow into philosophers, will Strauss's students even consider the possibility that they have been duped, that Strauss's treasure map was exoteric, a ruse designed only to draw them into philosophy. By this time, however, they will have come to experience the happiness of philosophizing, and could only thank Strauss for his benevolent pedagogical deceptions.

Second, Strauss's exoteric adoption of the ancient model of esotericism, through its insistence on an unbridgeable divide between the wise and the vulgar, seduces students into a life of philosophy by appealing directly to their vanity, a vice which so often characterizes the young. Strauss's students come to believe that, through a combination of their own natural gifts and their great good fortune to be blessed with a true philosopher as a teacher, they can enter the ranks of an ancient philosophical brotherhood. In this way, as Drury writes, "Strauss seduces young men into thinking that they belong to a special and privileged class of individuals that transcend ordinary humanity and the rules applicable to other people." ${ }^{\text {,4 }}$ Such elitism infuriates liberal egalitarians, thus exposing Strauss and his followers to a great risk of at least some form of persecution, be it ever so mild as social ostracism within the academy. Furthermore, the existence of a class of philosophically inclined (though not yet philosophical) pseudo-Supermen cannot serve to benefit our liberal democratic society. In this way, Strauss's exoteric use of the ancient model of esotericism can be justified under neither the ancient nor the modern models of esotericism, but only by the educational model.

If anything, Strauss might have been too successful in his use of esotericism for pedagogical purposes. He has regularly been accused of seducing a mass of his students, plus 
their students and their students in turn, not into adopting the philosophical way of life, or even a life of legitimate philosophical scholarship, but into adopting something known as "Straussianism," “a quasi-religious 'faith' in which [Strauss's] followers 'believe' less as students than as 'disciples.",45 The Straussian cult is seen as embracing Strauss's teachings in the manner in which the masses accept the philosophical truth under the modern model of esotericism, not as knowledge, but as true opinion accepted on authority. "It is ironic," Drury writes, "that the 'young men who love to think' and who are destined to become the heirs of Strauss are characterized by their willingness to accept Strauss's authority without question."46 What Drury fails to consider is the possibility that Strauss may have agreed with her assessment that the creation of such a cult is an evil, albeit an evil necessary for the preservation of the philosophical way of life. ${ }^{47}$ As his puppies grow into full-fledged philosophers, it would be Strauss's hope that they abandon the dogmatism of their youth, a dogmatism that was necessary only in the early stages of their philosophical education. ${ }^{48}$ If many of them do not, and remain forever mired in a cultish "Straussianism," then the flourishing of this cult must be understood as a negative externality from the production of non-dogmatic scholars and, in certain fortunate instances, genuine philosophers. In light of such a possibility, it seems that Strauss may have intended that his zetetic teachings be so ironically dogmatized, that he may have used the phenomenon of dogmatic Straussianism for his own pedagogical purposes.

Perhaps a better metaphor for the phenomenon of Straussianism than that of a "faith" or a "cult" is thus that of Freemasonry. In Lessing's dialogue "Ernst and Falk," discussed in Strauss's posthumously published essay on "Exoteric Teaching," the practitioner of esotericism is identified wit the member of such a fraternity; a "Freemason" is defined, in Strauss's paraphrase, as a man who "must know truths which ought better be concealed." 49 If they believe that they are 
the philosophical elect of the ancient model of esotericism, Straussians are in this sense Freemasons. Like the literal Freemasons, they are attracted to the secretive society for the sense of superiority it gives them and for the mystic truths it promises to reveal eventually. ${ }^{50}$ Yet it is often the case with Freemasonry that, unlike the lesser masons, the master mason knows that Freemasons are in no way superior to others, and that there are no mystic truths to be revealed. He understands that the brotherhood exists solely for the sake of fostering an international community devoted to virtue, but understands that such an international community holds little attraction in itself. The secrecy and rituals that give initiates a sense of superiority, as well as a hope to learn some mystic truth, are a necessary means of recruiting members for the club, a club which itself exists only as a means of actualizing higher goods. ${ }^{51}$ Strauss may have been a master mason of this type, the leader of a fraternity whose true purpose was hidden by an exoteric mask of secrecy and superiority. If we accept that his apparent advocacy of alternately the modern and then the ancient accounts of esotericism is merely exoteric, and that Strauss's true belief is that the primary purpose of esotericism is educational, such Freemasonry would be one of the most powerful pedagogical tools at his disposal.

As the Anti-Masons of the nineteenth century argued so vehemently, however, it is inherently dangerous to a democratic polity to have elitist secret societies wielding any considerable degree of social or political power, even when this power is allegedly wielded only for the most enlightened of ends. And although the most extreme allegations about the political power of the Straussian "cult" are best dismissed along with all other such conspiracy theories, the very existence of Freemasonic "Straussianism" raises legitimate moral and political concerns. To be sure, if Strauss's hyperbolic praise of philosophy is to be taken literally_if philosophy is indeed the only thing of value in the world - then the possibility of this way of life must be 
preserved by any means necessary. This would suggest a roughly Nietzschean picture of ethics and politics, one in which all human individuals and institutions are to be used as mere means for the production of humanity's highest specimens, the few creative individuals whose achievements justify existence as a whole. Yet it seems more likely that, while philosophers and their work are of very great value indeed, there are also other values in ethics and politics with which this value must compete. The propagation of the philosophical way of life thus may not be worth the danger posed to our liberal democracy by the persistent power of an elitist Freemasonic order. Indeed, we may wonder whether philosophy might survive perfectly well without the artificial inducements provided by Freemasonic membership. Is the initial appearance of truth actually as ugly as Strauss maintained it to be, or might gaining knowledge be sufficiently appealing in itself to lure potential philosophers without added, artificial inducements? $?^{52}$

In its insistence that students must be seduced to philosophy even if this seduction poses real dangers to the polity, the educational model of esotericism lacks the characteristic conservative virtues of the ancient model, the sense of political responsibility which seeks to protect the existing order from the forces which could destroy it. At the same time, it also lacks the characteristic liberal virtues of the modern model: its fundamental egalitarianism and its emphasis on the widespread propagation of truth. To be sure, the educational model need not embrace the natural divide between the philosophers and the multitude assumed by the ancient model, but the natural superiority of a wise elite has here been replaced by the artificial superiority of an educated elite, an elite which has been provided with philosophical training and successfully seduced to a life of scholarship or philosophy while their fellows have not. Like the hierarchy of Plato's kallipolis, moreover, this hierarchy depends upon lies of only questionable 
nobility—lies here directed, not to the multitude to justify their subjugation, but to the elite to justify their superiority. Rather than telling the masses that they are mere iron, Strauss's exoteric embrace of the ancient model of esotericism leaves his followers believing that they are golden. This myth of natural hierarchy is meant to seduce students to a life spent in the pursuit of truth, but it is legitimate to ask whether in the promotion of such a lifestyle we may justifiably violate the spirit of intellectual honesty central to the practice of philosophy itself.

Yet before we are too quick to condemn Strauss's pedagogical practice as unnecessary, morally repugnant or politically irresponsible — a practice which dishonors the very form of life it is meant to promote - we must remember that this account of esotericism may not actually be Strauss's own. This essay's interpretation of Strauss as writing esoterically on the subject of esotericism for educational purposes must necessarily remain a tentative one. The interpretation of esoteric texts is hardly a precise science resulting in certain knowledge; as Strauss himself observes, "reading between the lines will not lead to complete agreement among scholars" (PAW, p. 30). But this essay has come to its conclusions without ever accepting that any work of or passage by Strauss necessarily reflects his true teaching, acknowledging the possibility that any doctrine which one might glean from a text by Strauss may be entirely exoteric, including Strauss's teachings on esotericism itself. Regardless of whether he would agree with our conclusions, it is difficult to imagine Strauss taking issue with this zetetic method. Skepticism, he repeatedly insists, is the essence of philosophy, and it is this insistence which forever prevented Strauss from becoming a dogmatic Straussian. "As long as there is no wisdom but only the quest for wisdom," Strauss writes, "the evidence of all solutions is necessarily smaller than the evidence of the problems. Therefore the philosopher ceases to be a philosopher at the 
moment at which the 'subjective certainty' of a solution becomes stronger than his awareness of the problematic character of that solution. At that moment the sectarian is born." ${ }^{, 53}$ 


\section{Endnotes}

${ }^{1}$ Quoted in a letter by Frederich Engels to Conrad Schmidt, August 3, 1890. Karl Marx and Frederick Engels, Selected Correspondence, 1846-1895. Translated by Donna Torr (New York: International Publishers, 1942), p. 472. Also available online, edited by Brian Basgen, at the Marx/Engels Internet Archive (Marxists.org), http://www.marxists.org/archive/marx/works/1890/1etters/90_08_05.htm.

2 The scholarly debates over Strauss's true beliefs are voluminous, and their range has been summarized well both by Robert B. Pippin “The Modern World of Leo Strauss," (Political Theory 20:3 [1992]: 448-472, p. 449) and by Nathan Tarcov ("Philosophy and History: Tradition and Interpretation in the Work of Leo Strauss," Polity 16:1 [1983]: 5-29, p. 10). In the spring of 2003, these scholarly debates spilled over to the popular press, as The New Yorker, The New York Times and other periodicals came to attribute much of the Bush administration's foreign policy to Strauss's influence, setting off a brief storm of controversy. Perhaps the best of these popular treatments of Strauss was by Janet Heer ("The Philosopher," The Boston Globe, 11 May 2003, p. H1). The idea that Strauss was a "Jewish Nazi” is attributed to Shadia Drury in Heer's article. Strauss describes himself as a "friend" of liberal democracy in Liberalism Ancient and Modern (Chicago: University of Chicago Press, 1968), p. 24. (Henceforth cited parenthetically as LAM.)

${ }^{3}$ Leo Strauss, "Farabi’s Plato" in Louis Greenberg: Jubilee Volume (New York: American Academy of Jewish Research, 1954), p. 375. The same phrase is also used in Strauss, Persecution and the Art of Writing (Chicago: University of Chicago Press, 1988), p. 14. (Henceforth cited parenthetically as $P A W$.) 
4 "Strauss merges with the authors he discussed," Allan Bloom writes, "and can be understood to be nothing more than their interpreter" ("Leo Strauss: September 20, 1889-October 18, 1973," Political Theory 2:4 [1974]:372-392, p. 376).

5 A note on terminology: Ideally, the adjectives "esoteric" and "exoteric" would be applied exclusively to teachings or doctrines themselves - teachings or doctrines intended for the few and for the many, respectively - and not to the texts which contain those doctrines. The literary practice of interest for this essay involves simultaneously communicating true, esoteric teachings to the few and beneficial (if not entirely truthful) exoteric teachings to the many through the composition of a single text. Following common parlance, I will refer to this practice as "esotericism," and to the multiple-level works produced through it as "esoteric texts." Of course, the practice of multiple-level composition might just as easily be referred to as "exotericism" which produces "exoteric texts." Michael Kochin, for one, prefers this latter option (See Kochin, "Morality, Nature and Esotericism in Leo Strauss's Persecution and the Art of Writing," The Review of Politics 64:2 [2002]: 261-283, p. 261), and this is indeed the choice that Strauss himself makes in "Persecution and the Art of Writing (PAW, pp. 35-36) and in the posthumously published essay "Exoteric Teaching" (In The Rebirth of Classical Political Rationalism: An Introduction to the Thought of Leo Straus. Essays and Lectures by Strauss, Selected and Introduced by Thomas L. Pangle. [Chicago: University of Chicago Press, 1989]: 63-71; Henceforth cited parenthetically as $R C P R$ ). Yet referring to "exoteric literature" makes it difficult to distinguish between multiple-level texts containing hidden esoteric doctrines and single-level texts which convey exoteric doctrines alone. Warren Harbison chooses to speak of “irony" and "ironic texts," but this seems to confuse one particular literary technique for communicating exoteric and esoteric teachings simultaneously with the more general 
phenomenon of multiple-level communication using any of a variety of techniques ("Irony and Deception," The Independent Journal of Philosophy 2 [1978]: 89-94). I thus choose to speak of “esotericism," not out of any great attachment to this term, but simply because it is less awkward and less likely to confuse than the alternatives.

${ }^{6}$ In this way, I hope to continue Nathan Tarcov's project establishing that, just as Marx was not a Marxist, Strauss was not a Straussian — a project begun in Tarcov's essay “On a Certain Critique of 'Straussianism”" (In Kenneth L. Deutsch and Wakter Nicgorski, eds., Leo Strauss: Political Philosopher and Jewish Thinker .[Lanham, MD: Rowman \& Littlefield Publishers, 1994]: 259274). Tarcov defines "Straussianism" as "that complex of writings, teachings and other practices belonging to those students, students of students, followers and imitators of Strauss" (p. 263) which is often taken to have as its goal the application of "classical political philosophy as the solution to modern political problems” (p. 265). Tarcov's essay discusses Strauss's open and adamant rejection of this "Straussian" goal as a general program for contemporary political philosophers, a rejection stated most adamantly in Strauss's 1946 essay “On a New Interpretation of Plato's Political Philosophy" (Social Research 13:3, [1946]: 326-67). The present essay can be seen as dealing with Strauss's less obvious rejection of one element of ancient political philosophy — the ancient account of esoteric writing — in Strauss's more ambiguous work on the subject of esotericism.

${ }^{7}$ Stanley Rosen, Hermeneutics as Politics (New York: Oxford University Press, 1987), p. 123.

${ }^{8}$ Strauss, What is Political Philosophy? And Other Studies (Chicago: University of Chicago Press, 1988), p. 221. (Henceforth cited parenthetically as WPP).

${ }^{9}$ Paul J. Bagley, “On the Practice of Esotericism,” Journal of the History of Ideas. 53:2, (1992): 231-247, p. 246. 
${ }^{10}$ I wish to thank one of the anonymous reviewers of this essay for pointing out that, strictly speaking, the account of esotericism discussed here is not actually "unconditional." It is still a response to certain conditions, albeit necessary and unchanging ones.

${ }^{11}$ See Plato, Letter VII 341c-3, on how certain truths are never of "any benefit to men, except to a few, i.e., to those who could with a little guidance discover the truth by themselves" (Translated by Glenn R. Morrow in Plato, Complete Works. Edited, with Introduction and Notes, by John M. Cooper. [Indianapolis: Hackett Publishing, 1997]: 1646-1667, p. 1659). As Josiah Ober has persuaded me in conversation, however, even if we assume Plato's Seventh Letter to be authentic, it is hardly evident that Plato was an advocate of unconditional esotericism. Although there are also passages which might inspire this account of esotericism by such ancient authors as Aristophanes and Isocrates, most classicists believe that the account was fully formulated only by later, medieval writers. For the clearest such medieval statement of the "ancient" account of esotericism, see the Dedicatory Epistle and Introduction to the First Part of Moses Maimonides' The Guide of the Perplexed (Translated with an Introduction and Notes by Shlomo Pines with an Introductory Essay by Leo Strauss. [Chicago: University of Chicago Press, 1963], pp. 3-20). For an interpretation of Maimonides' esotericism, which has strong parallels to the present account of Strauss's esotericism, see Michael Frazer, “A Critical Re-Evaluation of the Esoteric Character of Maimonides' Guide of the Perplexed," in Douglas W. Shrader, ed., Children of Athena. (Oneonta, NY: Oneonta Philosophy Studies, 1999).

${ }^{12}$ Perhaps the clearest eighteenth-century exposition of the modern, Enlightenment account of conditional esotericism can be found in John Toland's 1720 London pamphlet Clidophorus, or, of the Exoteric and Esoteric Philosophy: That is, Of the External and Internal Doctrine of the Ancients: The one open and public, accommodated to popular prejudices and the Religions 
establish'd by Law; and the other private and secret, wherein, to the few capable and discrete, was taught the real Truth stript of all disguises. The doctrine of this pamphlet that esoteric writing is a temporary resort necessary only in times of censorship, one meant to advance the cause for free thought and eventually bring about an end to this persecution and hence the need for esotericism, is discussed in Annabel Patterson, Reading Between the Lines (Madison, Wisconsin: The University of Wisconsin Press, 1993), pp. 22-23. Interestingly, Toland attributes his account to "the Ancients;" Strauss, of course, would argue that Toland is far more useful as a paradigmatic example of an Enlightenment thinker than as a successful commentator on premodern esotericism.

${ }^{13}$ Strauss, "The Spirit of Sparta or the Taste of Xenophon", Social Research 6:4, (1939): 502536. (Henceforth Henceforth cited parenthetically as SS). The passage under discussion, from which all of the quotations in this paragraph are drawn, is on pp. 534-535.

${ }^{14}$ Shadia B. Drury, Leo Strauss and the American Right (New York: St. Martin's Press, 1997), p. 231. (Henceforth cited as LSAR).

${ }^{15}$ Some of the clearest of these statements are to be found in Strauss's repeated praise of Lessing as the last great advocate (until, perhaps, Strauss himself) of the ancient account of esotericism as "an intelligible necessity for all times" (RCPR, p. 64, see also $P A W, \mathrm{p} .28)$. Whether Lessing was indeed an advocate of esotericism in the ancient mode is, however, open to debate; see the discussion of "Ernst and Falk" at the conclusion of the present essay.

${ }^{16}$ For the idea that Strauss was not a "Straussian" in this way, see Tarcov, "On a Certain Critique of Straussianism," as discussed in footnote 5 in the present essay.

${ }^{17}$ The idea that the modern account of esotericism, with its emphasis on persecution, is at most "incidental" to Strauss's true account of the phenomenon goes back at least as far as the review 
of Persecution and the Art of Writing by George H. Sabine (Ethics, 63:3:1, [1953]:. 220-222, p. 220). For a recent pro-Straussian identification of Strauss's esotericism with the ancient model, see Kochin, op. cit. For a recent anti-Straussian example of the same identification, in addition to that by Drury cited above, see Patterson, op. cit., pp. 23-24. Interestingly, Patterson is herself a passionate exponent of the modern, Enlightenment account of esotericism which she finds in Toland, but refuses to attribute this account to Strauss, and instead excoriates him for the inegalitarianism of his (alleged) ancient account of the phenomenon.

${ }^{18}$ On the notion of a "politic philosopher," see Thomas L. Pangle's Introduction in RCPR: viixxxviii, p. xix.

${ }^{19}$ See, e.g., Rosen, op. cit., p. 117.

${ }^{20}$ As an anonymous reviewer of this essay correctly pointed out, the year of Bismarck's dismissal was the same year that Nietzsche's final descent into madness ended his philosophical work once and for all. While Nietzsche wrote in Bismarckian Germany, however, he was only widely read after 1890. Perhaps Strauss's reference to "post-Bismarckian Wilhelmian Germany" as a time and place "in which men can attack in writings accessible to all both the established social or political order and the beliefs on which it is based" is thus a reference to the era in which Nietzsche's works became popular, if not when they were composed.

${ }^{21}$ Laurence Lampert, Leo Strauss and Nietzsche (Chicago: University of Chicago Press, 1996), p. 184. For Strauss's own, early account of his relationship to Nietzsche in this regard, including a critique of Nietzsche's polemical boldness, see his letter of June 23, 1935 to Karl Löwith in "Correspondence: Karl Löwith and Leo Strauss," The Independent Journal of Philosophy 5/6, (1988): 177-192, pp. 182-184. 
${ }^{22}$ Drury, The Political Ideas of Leo Strauss (London: MacMillan Press, 1988), pp. 195-196. (Henceforth cited as PILS) See also Drury, LSAR, especially Ch. 1.

${ }^{23}$ Miriam Galston argues along similar lines in a discussion of Maimonides, Avicenna and Farabi, reasoning that if any of an author's teachings may be merely exoteric, concealing an esoteric truth, we must consider the possibility that an author's teachings on the subject of esotericism may themselves be merely exoteric. "This possibility should be considered," Galston writes, "not out of perversity, but as a consequence of taking these works [i.e., those of medieval esotericists] on their own terms" (Politics and Excellence: The Political Philosophy of Alfarabi [ Princeton: Princeton University Press, 1990], p. 53).

${ }^{24}$ Bagley, op. cit., p. 240. Strauss himself praises Lessing as one who "wrote between the lines about the art of writing between the lines," one whose strong, unconditional account of esotericism demanded that its principles govern "his own literary activity" $(R C P R, \mathrm{p} .64)$.

${ }^{25}$ Rosen, op. cit., p. 155.

${ }^{26}$ Paul A. Cantor, "Leo Strauss and Contemporary Hermeneutics," in Alan Udoff, ed. Leo Strauss's Thought: Toward a Critical Engagement (Boulder: Lynne Riener Publishers, 1991), p. 270.

${ }^{27}$ Of course, Strauss's detractors have gone far further than merely criticizing Straussian hermeneutics for never leading to absolute certainly, regularly observing that Strauss's approach to interpretation necessarily puts his conclusions "outside the realm of falsification and debate" (John G. Gunnell, “The Myth of the Tradition,” The American Political Science Review, 72:1 [1978]: 122-134, p. 131). It is in this way, J.G.A. Pocock has argued, that Straussianism has become a "closed ideology," and "the followers of Leo Strauss" have become "an intolerable sect of true believers" ("Prophet and Inquisitor: Or, a Church Built Upon Bayonets Cannot 
Stand: A Comment on Mansfield's 'Strauss's Machiavelli,'” Political Theory 3:4 [1975]:385-

401, p. 399).

${ }^{28}$ Cantor, op. cit., p. 273.

${ }^{29}$ See, for example, Strauss, The City And Man (Chicago: University of Chicago Press, 1964), p. 54 and $R C P R$, p. 66.

${ }^{30}$ See also "Farabi's Plato," p. 375, where the words "in which he speaks in his own name" are instead "setting forth what he presents as his own doctrine."

${ }^{31}$ See Gotthold Ephraim Lessing, "Ernst and Falk" (1778/80):

ERNST: If even the Freemasons who know the secret of their order are not able to convey it in so many words, how do they spread their order nevertheless?

FALK: Through their deeds. They let good men and youths, whom they consider worthy of close company, surmise, guess or observe their deeds, insofar as they can be observed...

(Translated by William L. Zweibel in Nathan the Wise, Minna von Barnhelm, and Other Plays and Writings. Edited by Peter Demetz [New York: Continuum Publishing, 1994]:277-308, p. 281).

${ }^{32}$ Rosen, op. cit., p. 114.

${ }^{33}$ Ibid., p. 115, quoting Strauss, "How to Begin to Study The Guide of the Perplexed," Introductory Essay to Maimonides, op. cit., xi-lvi, p. xvii.

${ }^{34}$ Rosen, p. 115.

35 This feature of Strauss's commentaries on canonical texts has long been observed by Strauss's admirers, who repeatedly praise Strauss for forcing his readers "through a process of learning in which the most meticulous attention to detail is required for the highest flights of speculation, 
and almost nothing is made available without effort on their part" (Harvey Mansfield, "Strauss's Machiavelli," Political Theory 3:4 [1975]: 372-384, p. 376).

${ }^{36}$ Patterson, op. cit., is a good example of such a liberal, one who reviles Strauss for his (apparent) endorsement of the ancient, inegalitarian account of esotericism, but who herself gladly endorses the modern account of the practice, in which esotericism is a tool for resisting oppression and advancing the cause of free thought.

${ }^{37}$ Rosen, op. cit., p. 113.

${ }^{38}$ This particular use of esoteric writing is often associated with Farabi, and is discussed by Strauss in "Farabi’s Plato," p. 387. Galston (op. cit., pp. 50-51) contrasts Farabi’s "dialectical” use of multiple-level writing with the more radical sort of esotericism attributed to Farabi (and other such "ancients") by Strauss, but the difference between her understanding of Farabi's literary technique and Strauss's interpretation thereof seems exaggerated.

${ }^{39}$ See also $S S$, p. 535.

${ }^{40}$ Perhaps the best such commentary on the educational purposes of Straussian esotericism is in Tarcov, "Philosophy and History," pp. 16-29. Another good commentary on Strauss focusing on the educational purposes of esotericism is Harbison, "Irony and Deception."

${ }^{41}$ The idea that the "preservation of philosophy as a human possibility" requires "a broad school of philosophical scholarship that recognizes that philosophy is actual in the freedom of thought attained" was first suggested to me by one of the anonymous reviewers of this article.

${ }^{42}$ David Lewis Schaefer, "Leo Strauss and American Democracy: A Response to Wood and Holmes," in Deutch and Nicgorski, eds., p. 345.

${ }^{43}$ Lampert, op. cit., p. 125.

${ }^{44}$ Drury, PILS, p. 193. 
${ }^{45}$ Schaeffer, p. 339 quoting Gordon Wood, "The Fundamentalists and the Constitution," The New York Review of Books, 18 February 1988. For another version of this accusation, see Pocock, op. cit. ${ }^{46}$ Drury, PILS, p. 201.

${ }^{47}$ David Lawrence Levine counters Drury's line of argument in a rather different way, by noting that one must not "precipitously judge a teacher by the excesses of his students, as was done in the case of Socrates." "Without Malice But with Forethought: A Response to Burnyeat," in Deutsch and Nicgorski, eds, 353-372, p. 354). Levine seems to assume that Strauss never foresaw, let alone intended, the "excesses of his students."

${ }^{48}$ In this, Strauss may indeed be a secret Nietzsche, albeit not in the sense discussed earlier. Instead, Strauss may be taking inspiration from Zarathustra's famous message to his disciples: "Now I bid you lose me and find yourselves, and only when you have all denied me will I return to you" (Friedrich Nietzsche, Also Sprach Zarathustra. [1883-1885], Translated by Kaufmann as Thus Spoke Zarathustra in The Portable Nietzsche [New York: Penguin Books, 1954/1982]: 103-440, Book I "On the Gift-Giving Virtue," 3, p. 190).

${ }^{49}$ Strauss in $R C P R$, p. 64 . The Zweibel translation defines a freemason as one who "recognizes truths which are better left unsaid" (Lessing, op. cit., p. 285).

${ }^{50}$ See Plato's complaint concerning Dion's clique in the Seventh Letter, that they are a circle of friends drawn together "not through philosophy, but by way of that facile comradeship which is the basis of most friendship, and which is cultivated by hospitality and mystic rites and initiation into secrets" (Letter VII 333e, in Cooper, ed., op. cit., p. 1653).

${ }^{51}$ Although "Ernst and Falk" is a highly enigmatic work, its account of freemasonry might be interpreted along these lines. See especially the "Fourth Conversation" (Lessing, op cit., pp. 295- 
302). For a different interpretation of the dialogue, one which suggests that "the similarities between Strauss and Lessing are altogether superficial,” see Drury, LSAR, pp. 46-48.

${ }^{52} \mathrm{I}$ have to thank one of the anonymous reviewers of this article for raising this important question, one which I must leave unanswered for now.

${ }^{53}$ Strauss, On Tyranny. Revised and Expanded Edition, Including the Strauss-Kojève Correspondence. Edited by Victor Gourevitch and Michael S. Roth. (New York: The Free Press, 1991), p. 196. This passage is also quoted by Steven B. Smith in "Leo Strauss's Platonic Liberalism," Political Theory. 28:6, [2000], 787-809, p. 800. These concluding thoughts on Strauss's skepticism were guided by Smith's article, as this essay as a whole was guided by Smith's advice.

Michael L. Frazer is a doctoral candidate in the Department of Politics at Princeton University. He is currently completing a dissertation, entitled Liberal Sympathies: Grounds for a Commitment to Justice, which defends a non-rationalist approach to liberal-democratic theory through a reexamination of the moral sentimentalism of the Scottish Enlightenment and its German critics. 